\title{
Influence of carbon sources and electron shuttles on ferric iron reduction by Cellulomonas sp. strain ES6
}

\author{
Robin Gerlach • Erin K. Field • \\ Sridhar Viamajala $\cdot$ Brent M. Peyton • \\ William A. Apel · Al B. Cunningham
}

Received: 18 September 2010/Accepted: 31 January 2011/Published online: 13 February 2011

(C) Springer Science+Business Media B.V. 2011

\begin{abstract}
Microbially reduced iron minerals can reductively transform a variety of contaminants including heavy metals, radionuclides, chlorinated aliphatics, and nitroaromatics. A number of Cellulomonas spp. strains, including strain ES6, isolated from aquifer samples obtained at the U.S. Department of Energy's Hanford site in Washington, have been shown to be capable of reducing $\mathrm{Cr}(\mathrm{VI})$, TNT, natural organic matter, and soluble ferric iron [Fe(III)]. This
\end{abstract}

R. Gerlach · E. K. Field · B. M. Peyton ·

A. B. Cunningham

Center for Biofilm Engineering, Montana State

University, Bozeman, MT 59717, USA

R. Gerlach $(\bowtie) \cdot$ B. M. Peyton

Department of Chemical and Biological Engineering, Montana State University, Bozeman, MT 59717, USA

e-mail: robin_g@biofilm.montana.edu

\section{E. K. Field}

Department of Microbiology, Montana State University, Bozeman, MT 59717, USA

\section{S. Viamajala}

Department of Chemical and Environmental Engineering, The University of Toledo, Toledo, $\mathrm{OH} 43606$, USA

\section{W. A. Apel}

Biological Systems Department, Idaho National Laboratory, Idaho Falls, ID 83415, USA

\author{
A. B. Cunningham \\ Department of Civil Engineering, Montana State \\ University, Bozeman, MT 59717, USA
}

research investigated the ability of Cellulomonas sp. strain ES6 to reduce solid phase and dissolved Fe(III) utilizing different carbon sources and various electron shuttling compounds. Results suggest that Fe(III) reduction by and growth of strain ES6 was dependent upon the type of electron donor, the form of iron present, and the presence of synthetic or natural organic matter, such as anthraquinone-2,6-disulfonate (AQDS) or humic substances. This research suggests that Cellulomonas sp. strain ES6 could play a significant role in metal reduction in the Hanford subsurface and that the choice of carbon source and organic matter addition can allow for independent control of growth and iron reduction activity.

Keywords Fermenters - Anthraquinone-2,6disulfonate (AQDS) · Humics · HFO - Ferrihydrite . Goethite $\cdot$ Magnetite $\cdot$ Maghemite $\cdot$ Hematite

\section{Introduction}

The reductive transformation of oxidized contaminants by ferrous iron, $\mathrm{Fe}(\mathrm{II})$, has received increasing interest in the recent years. Electron transfer from $\mathrm{Fe}$ (II) usually occurs fast and is non-specific so that a broad spectrum of compounds can react with surfaceassociated and soluble Fe(II). This makes Fe(II)-based remediation technologies an attractive alternative or addition to traditional cleanup strategies. Potentially treatable contaminants include heavy metals such as 
$\mathrm{Cr}(\mathrm{VI})$, radionuclides such as $\mathrm{U}(\mathrm{VI})$, chlorinated aliphatics such as carbon tetrachloride (CT) and trichloroethylene (TCE) as well as nitroaromatics such as 2,4,6-trinitrotoluene (TNT) (Eary and Rai 1988; Erbs et al. 1999; Amonette et al. 2000; Fredrickson et al. 2000b; Lee and Batchelor 2002a, b; Hofstetter et al. 2003; Borch et al. 2005).

In subsurface environments, $\mathrm{Fe}$ (II) can be produced chemically or biologically and engineered in situ remediation schemes utilizing the reactivity of subsurface $\mathrm{Fe}$ (II) have been demonstrated (Heijman et al. 1995; Yin and Allen 1999; Chilakapati et al. 2000). Remediation based on the biological reduction of ferric $[\mathrm{Fe}(\mathrm{III})]$ minerals has been suggested as a low-cost technology for heavy metal and radionuclide immobilization at US Department of Energy (DOE) and other sites (Istok et al. 1999). It has been shown that a wide variety of bacteria, including but not limited to ironrespiring, fermenting, sulfate-reducing, halorespiring, and methanogenic bacteria, are able to reduce dissolved and solid phase ferric iron, either directly or indirectly, in the presence of electron shuttling compounds (Lovley et al. 1991; Benz et al. 1998; Cervantes et al. 2002).

Past research regarding biological Fe(III) reduction has focused mainly on Gram-negative metal-reducers such as Geobacter, Shewanella and Desulfovibrio spp. (Nealson and Saffarini 1994; Roden and Zachara 1996; Zachara et al. 1998; Lovley and Blunt-Harris 1999; Dong et al. 2000; Newman 2001; Liu et al. 2002; Royer et al. 2002b; Saffarini et al. 2002). In general, Gram-positive fermenters have received much less attention for their potential role in $\mathrm{Fe}$ (III) reduction and contaminant remediation. Previously, isolates were obtained from contaminated and uncontaminated subsurface locations at the DOE site in Hanford, Washington that were capable of $\mathrm{Cr}(\mathrm{VI})$ reduction (Smith et al. 2002; Viamajala et al. 2007). Of the nine isolates obtained, eight were Gram-positive of which four were from the Cellulomonas genus. Additional studies with three of the Cellulomonas isolates-strain ES5, strain WS01 and strain WS18, demonstrated their ability to reduce U(VI) as well as soluble Fe(III) using lactate as the electron donor (Sani et al. 2002). Finally, bench scale column experiments using Cellulomonas sp. strain ES6 indicated prolonged periods of $\mathrm{Cr}(\mathrm{VI})$ reduction in columns containing microbially reduced hydrous ferric oxide (HFO) via abiotic reduction of $\mathrm{Cr}(\mathrm{VI})$ by surface associated $\mathrm{Fe}(\mathrm{II})$ and regeneration of $\mathrm{Fe}(\mathrm{II})$ through microbial reduction by strain ES6
(Viamajala et al. 2008). This study continued to focus on strain ES6 in order to further investigate relevant microbial reduction mechanisms. In specific, the direct and indirect reduction of Fe(III) minerals by strain ES6 was assessed in order to better understand the potential for Fe(II)-based remediation through stimulation of indigenous bacteria at the Hanford site.

The choice of electron donor for Fe(III) reduction will likely determine the growth of a particular group of organisms and is important in order to achieve effective $\mathrm{Fe}$ (II) production to maintain electron flow necessary for biologically mediated contaminant reduction. The electron donor that is ultimately selected for field use will likely depend on regulatory approval, cost, availability, and ability to sustain growth of the microorganisms of interest.

While microorganisms can directly reduce $\mathrm{Fe}(\mathrm{III})$ through the addition of an electron donor, Fe(III) can also be reduced indirectly through the use of electron shuttles such as naturally occurring organic matter or the addition of quinone moieties. Previous studies have already shown that the presence of an electron shuttle can increase $\mathrm{Fe}(\mathrm{III})$ reduction rates and extent (Fredrickson et al. 1998, 2000a; Lovley et al. 1998; Lovley and Blunt-Harris 1999; Nevin and Lovley 2000; Royer et al. 2002b; Jiang and Kappler 2008; Bauer and Kappler 2009; Wolf et al. 2009). To design and implement effective Fe-based bioremediation strategies, it is important to clearly understand interactions of site-specific bacteria, such as strain ES6, with the numerous types of iron minerals that might be present (Lovley and Phillips 1986a; Lovley 1997).

The goal of these studies was to determine the influence of various carbon sources (electron donors) and electron shuttling compounds, such as synthetic and natural organic matter, on the growth and Fe(III) reduction capabilities of Cellulomonas sp. strain ES6 (henceforth referred to as strain ES6) of dissolved and solid phase $\mathrm{Fe}(\mathrm{III})$.

\section{Materials and methods}

Experimental

Organism and culture conditions

Strain ES6 was maintained in frozen stock cultures containing tryptic soy broth (TSB, $30 \mathrm{~g} / \mathrm{l}$, Difco 
Laboratories) with $20 \%$ glycerol at $-70^{\circ} \mathrm{C}$. Cells were pre-cultured in TSB for $24 \mathrm{~h}$ on a horizontal shaker at $150 \mathrm{rpm}$ and $30^{\circ} \mathrm{C}$, transferred into fresh TSB, and grown again for $18 \mathrm{~h}$ in TSB (each $1 \%$ initial inoculum). Cultures were then harvested via centrifugation $\left(5,860 \times g, 20 \mathrm{~min}, 4^{\circ} \mathrm{C}\right)$, washed in oxygenfree synthetic groundwater (SGW), and re-suspended in SGW to the desired cell concentration.

\section{Media composition}

Synthetic groundwater (SGW) modified from Petersen et al. (1994) was used for all experiments. The final concentrations of the constituents are listed in Table 1. Sodium metasilicate, sodium carbonate, sodium sulfate, yeast extract, and casamino acids were dissolved in deionized (DI) water and autoclaved at $121^{\circ} \mathrm{C}$. The autoclaved solution was boiled under an oxygen-free atmosphere of $\mathrm{N}_{2} / \mathrm{CO}_{2}(80: 20)$

Table 1 Composition of synthetic groundwater medium (SGW)

\begin{tabular}{|c|c|c|}
\hline Name & Formula & $\begin{array}{l}\text { Concentration in } \\
\text { SGW }(\mathrm{mg} / \mathrm{l})\end{array}$ \\
\hline Aluminium sulfate & $\mathrm{Al}_{2}\left(\mathrm{SO}_{4}\right)_{3} \cdot 18 \mathrm{H}_{2} \mathrm{O}$ & 0.123 \\
\hline Boric acid & $\mathrm{H}_{3} \mathrm{BO}_{4}$ & 0.6 \\
\hline $\begin{array}{l}\text { Calcium chloride } \\
\text { dihydrate }\end{array}$ & $\mathrm{CaCl}_{2} \cdot 2 \mathrm{H}_{2} \mathrm{O}$ & 8 \\
\hline Casamino acids & & 100 \\
\hline Cobalt sulfate & $\mathrm{CoSO}_{4} \cdot 7 \mathrm{H}_{2} \mathrm{O}$ & 0.109 \\
\hline Cupric sulfate & $\mathrm{CuSO}_{4} \cdot 5 \mathrm{H}_{2} \mathrm{O}$ & 0.08 \\
\hline Ferrous sulfate & $\mathrm{FeSO}_{4} \cdot 7 \mathrm{H}_{2} \mathrm{O}$ & 0.3 \\
\hline Lithium chloride & $\mathrm{LiCl}$ & 0.021 \\
\hline Magnesium hydroxide & $\mathrm{Mg}(\mathrm{OH})_{2}$ & 33.5 \\
\hline Manganese chloride & $\mathrm{MnCl}_{2} \cdot 4 \mathrm{H}_{2} \mathrm{O}$ & 0.629 \\
\hline Nickel chloride & $\mathrm{NiCl}_{2} \cdot 6 \mathrm{H}_{2} \mathrm{O}$ & 0.11 \\
\hline Potassium bromide & $\mathrm{KBr}$ & 0.03 \\
\hline Potassium chloride & $\mathrm{KCl}$ & 26.5 \\
\hline Potassium iodide & $\mathrm{KI}$ & 0.03 \\
\hline Sodium bicarbonate & $\mathrm{NaHCO}_{3}$ & 2519.7 \\
\hline Sodium carbonate & $\mathrm{Na}_{2} \mathrm{CO}_{3}$ & 160 \\
\hline Sodium metasilicate & $\mathrm{Na}_{2} \mathrm{SiO}_{3} \cdot 9 \mathrm{H}_{2} \mathrm{O}$ & 455 \\
\hline Sodium molybdate & $\mathrm{Na}_{2} \mathrm{MoO}_{4}$ & 0.01 \\
\hline Sodium selenate & $\mathrm{Na}_{2} \mathrm{SeO}_{4}$ & 0.05 \\
\hline Sodium sulfate & $\mathrm{Na}_{2} \mathrm{SO}_{4}$ & 6 \\
\hline Yeast extract & & 50 \\
\hline Zinc sulfate & $\mathrm{ZnSO}_{4} \cdot 7 \mathrm{H}_{2} \mathrm{O}$ & 0.106 \\
\hline
\end{tabular}

for $10 \mathrm{~min}$ and cooled to room temperature under the same oxygen-free atmosphere to avoid re-dissolution of atmospheric oxygen. Sterile, oxygen-free stock solutions of sodium bicarbonate, potassium chloride, calcium chloride, magnesium hydroxide, and the trace minerals were added. The medium was dispensed into Balch tubes (used as experimental reactors as described below) under the $\mathrm{N}_{2} / \mathrm{CO}_{2}$ atmosphere to maintain oxygen-free conditions.

\section{Iron minerals}

Goethite $(\alpha-\mathrm{FeOOH}, \mathrm{BET}$ specific surface area (SSA) $\left.16.7 \mathrm{~m}^{2} / \mathrm{g}\right)$, maghemite $\left(\gamma-\mathrm{Fe}_{2} \mathrm{O}_{3}\right.$, SSA $\left.43.9 \mathrm{~m}^{2} / \mathrm{g}\right)$, hematite $\left(\alpha-\mathrm{Fe}_{2} \mathrm{O}_{3}\right.$, SSA $\left.7.8 \mathrm{~m}^{2} / \mathrm{g}\right)$, and magnetite $\left(\mathrm{Fe}_{3} \mathrm{O}_{4}, \mathrm{SSA} 6.6 \mathrm{~m}^{2} / \mathrm{g}\right)$ were obtained from Alfa Aesar (Ward Hill, MA) with purities of $97 \%$ or greater. Hydrous ferric oxide (HFO, SSA $34.5 \mathrm{~m}^{2} / \mathrm{g}$ ) was synthesized using the procedure of Lovley and Phillips (1986b). In brief, $13.8 \mathrm{~g} \mathrm{FeCl}_{3}$ (Fisher Scientific) was dissolved in $400 \mathrm{ml}$ of deionized water and the solution $\mathrm{pH}$ was slowly adjusted to 7.0 using $\mathrm{NaOH}$. The resulting HFO suspension was diluted in SGW and used for the experiments within 1 month. The concentrations of total iron in the experiments were between 1.74 and $3.58 \mathrm{mM}$ depending on iron mineral and experimental goal. Stock solutions of Fe(III)citrate $(50 \mathrm{mM})$ and $\mathrm{Fe}(\mathrm{III})-\mathrm{NTA}(100 \mathrm{mM})$ were prepared by dissolving $1.225 \mathrm{~g}$ of $\mathrm{Fe}(\mathrm{III})$-citrate (Sigma, St. Louis, MO) and $1.62 \mathrm{~g} \mathrm{FeCl}_{3}$ with $1.91 \mathrm{~g}$ NTA in $70 \mathrm{ml}$ of deionized water, respectively. The Fe(III)-citrate solution was heated until dissolved and the $\mathrm{pH}$ of both solutions was slowly adjusted to 6.5 using $\mathrm{NaHCO}_{3}$. Both solutions were sparged with oxygen-free nitrogen gas, transferred into an oxygenfree glovebag, stirred overnight, filled to a total volume of $100 \mathrm{ml}$ each, and finally filter sterilized. It was determined that less than $1 \%$ of the Fe present in these solutions and suspensions was Fe(II).

\section{Batch experiments, $\mathrm{Fe}(\mathrm{III})$ reduction}

Oxygen-free SGW in Balch tubes containing iron minerals was amended with a carbon source, anthraquinone-2,6-disulfonate (AQDS, Sigma, St. Louis, MO), Elliott soil humic acid standard (International Humic Substances Society, MN, USA), and finally inoculated with strain ES6 before the tubes were crimp sealed using thick butyl rubber stoppers 
(Bellco Glass, Vineland, NJ). All manipulations were performed under an oxygen-free $\mathrm{N}_{2} / \mathrm{CO}_{2}$ atmosphere, and all additions were made using sterile, purged syringes and needles. The carbon sources investigated were added from oxygen-free stock solutions and included acetate, lactate, glycerol, xylose, sucrose, and molasses ("Brer Rabbit MolassesUnsulphured”, B\&G Foods Inc., Roseland, NJ). All carbon sources were added from $1 \mathrm{M}$ oxygen-free stock solutions to a final concentration of $10 \mathrm{mM}$. Molasses, which has a high content of sucrose (Prescott and Dunn 1983) was added from a concentrated stock solution to a final molasses concentration of $3.42 \mathrm{~g} / \mathrm{l}$. The initial bacterial concentrations were between $2.23 \times 10^{8} \pm 2.08 \times 10^{7}$ and $6.73 \times$ $10^{9} \pm 2.48 \times 10^{8}$ colony forming units (CFU) per $\mathrm{ml}$ (equivalent to between 25 and $770 \mathrm{mg}$ per litre of protein) depending on the experiment. Experiments were performed in triplicate with appropriate controls lacking bacteria, carbon source, AQDS, or humic substances. The vials were incubated statically at ambient temperature in the dark, sampled periodically using purged, sterile syringes and needles, and analyzed to determine the concentration of ferrous and total iron, protein, CFU, substrate, and metabolites as described below.

\section{Analytical}

\section{Iron quantification}

Total iron $\left(\mathrm{Fe}_{\mathrm{tot}}\right)$ and $\mathrm{Fe}(\mathrm{II})$ were determined using the ferrozine method. For $\mathrm{Fe}(\mathrm{II})$ analysis, sample aliquots were extracted with 0.5 or $2.5 \mathrm{~N} \mathrm{HCl}$. Extractions for $\mathrm{Fe}_{\text {tot }}$ were performed in the additional presence of $0.25 \mathrm{M} \mathrm{NH}_{2} \mathrm{OH}$ as a reductant. Commonly, the extraction time was $2 \mathrm{~h}$ but in some cases longer extraction times were used to verify complete extraction (Cooper et al. 2000; Royer et al. 2002b). Aliquots of acid extracts were added to a solution of $1 \mathrm{~g}$ ferrozine (Sigma, St. Louis, MO) in 11 HEPES buffer at $\mathrm{pH} 7$ and the absorbance was determined spectrophotometrically at $540 \mathrm{~nm}$ (EL 808 Microplate Reader, BIO-TEX Instruments, Winooski, VT).

\section{Colony forming units (CFU) and protein}

The concentration of CFU was determined after serial dilution of $0.1 \mathrm{ml}$ aliquots in phosphate buffered saline solution ( $\mathrm{pH} 7)$. Aliquots were spread onto tryptic soy agar (TSA, $40 \mathrm{~g} / \mathrm{l}$, Difco Laboratories), incubated for $48 \mathrm{~h}$ at $30^{\circ} \mathrm{C}$, and colonies were counted. No statistically significantly different counts were observed if plates were incubated for $72 \mathrm{~h}$ or longer. Total protein was measured by a modification of the Coomassie method (Bradford 1976). Cells were disrupted by mixing $0.5 \mathrm{ml}$ of sample with $0.5 \mathrm{ml}$ of $2 \mathrm{~N} \mathrm{NaOH}$. The mixture was heated for $30 \mathrm{~min}$ at $95^{\circ} \mathrm{C}$. After cooling the sample to ambient temperature, the $\mathrm{pH}$ was lowered to approximately 2 by adding $0.167 \mathrm{ml}$ of $6 \mathrm{~N} \mathrm{HCl}$. To this solution, $1 \mathrm{ml}$ of Coomassie Plus reagent (Pierce, Rockford, IL) was added and the absorbance was measured at $595 \mathrm{~nm}$ on a UV-vis spectrophotometer (Milton Roy Company Spectronic ${ }^{\circledR}$ GENESYS $5^{\mathrm{TM}}$, Rochester, NY). The assay was calibrated using $2 \mathrm{~g} / \mathrm{l}$ bovine serum albumin fraction $\mathrm{V}$ protein standard (Pierce, Rockford, IL) diluted to a concentration range of 0-30 $\mathrm{mg} / \mathrm{l}$ protein.

\section{Carbohydrate and fatty acid analysis}

Sucrose, glucose, fructose, glycerol, and lactate were quantified using a Dionex DX-300 ion chromatograph equipped with a Dionex PA10 column and a pulsed amperometric detector. Samples $(10 \mu \mathrm{l})$ were injected into a mobile phase consisting of $52 \mathrm{mM} \mathrm{NaOH}$ pumped at a flowrate of $1.2 \mathrm{ml} / \mathrm{min}$. Lactate, acetate, formate, propionate, iso-butyrate, and $n$-butyrate were analyzed using the same ion chromatograph equipped with a AS10 column, $25 \mu \mathrm{l}$ sample loop, and conductivity detector. The eluent consisted of a $3.5 \mathrm{mM}$ potassium tetraborate solution pumped at a flowrate of $1 \mathrm{ml} / \mathrm{min}$.

\section{Results}

Carbon source and electron acceptor influence on growth

Figure 1 shows the extent of bacterial growth [measured as change in protein ( $\Delta$ protein)] for lactate-, xylose-, and sucrose-amended ES6 cultures in the presence of several potential electron acceptors including $\mathrm{Fe}$ (III)-NTA, Fe(III)-citrate, HFO, fumarate, and oxygen. Protein data suggest that after 21 days xylose supported more bacterial growth than 


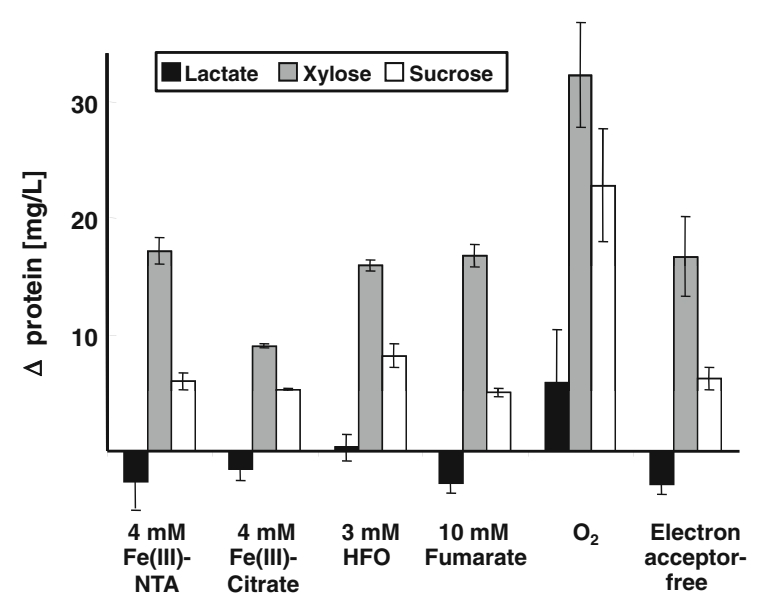

Fig. 1 Change in protein after 21 days of incubation of strain ES6 in the presence of lactate, xylose, sucrose, and several different potential electron acceptors. The electron acceptors tested included $\mathrm{Fe}$ (III)-NTA, Fe(III)-citrate, hydrous ferric oxide (HFO), fumarate, and oxygen. The initial protein concentration was $0.19 \pm 0.01 \mathrm{mg} / \mathrm{l}$. Error bars represent \pm one standard deviation $(n=3)$

sucrose regardless of the terminal electron acceptor used, while lactate supported bacterial growth only if oxygen was the terminal electron acceptor. For all three carbon sources tested, the greatest increase in protein was observed when oxygen was the terminal electron acceptor. When any of the other electron acceptors were used, no significant differences in growth were observed between the electron acceptorfree control and the other potential electron acceptors. These results suggest that both the electron donor and acceptor influence bacterial growth.

\section{Carbon source influence on $\mathrm{Fe}(\mathrm{II})$ production}

Both, xylose and sucrose, as electron donors supported some, though very little, reduction of hydrous ferric oxide (HFO, $3.22 \mathrm{mmol} / \mathrm{l}$ ) by strain ES6 as compared to uninoculated controls after 14 days (Fig. 2). The presence of $100 \mu \mathrm{M}$ AQDS significantly increased both the rate and extent of HFO reduction regardless of which carbon source was present. After 14 days, approximately $90 \%$ of the $\mathrm{Fe}(\mathrm{III})$ present had been reduced to $\mathrm{Fe}(\mathrm{II})$ by strain ES6 when AQDS was present and xylose was the carbon source utilized; only $7 \%$ had been reduced to $\mathrm{Fe}(\mathrm{II})$ in the absence of AQDS. When sucrose was the carbon source $61 \%$ of the available $\mathrm{Fe}$ was reduced to $\mathrm{Fe}(\mathrm{II})$ in the presence of AQDS compared

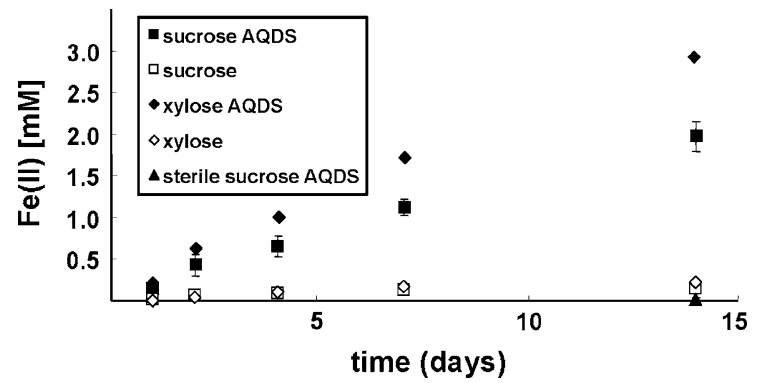

Fig. $2 \mathrm{Fe}$ (II) production from hydrous ferric oxide (HFO) by strain ES6 over time in the presence and absence of $10 \mathrm{mM}$ xylose or sucrose and $100 \mu \mathrm{M}$ AQDS. Error bars represent \pm one standard deviation $(n=3)$. Error bars are smaller than markers if not visible

to only $4 \%$ when AQDS was absent. The slight reduction of $\mathrm{HFO}$ after longer incubation times might be due to the production and release of compounds by strain ES6, which allowed for some reduction of solid phase Fe(III) even in the absence of AQDS.

While the most $\mathrm{Fe}(\mathrm{II})$ was produced in the treatment containing xylose and AQDS after 14 days, significant amounts of $\mathrm{Fe}(\mathrm{II})$ were also produced when molasses, glycerol or sucrose were present as well as AQDS (Fig. 3). When acetate was utilized as a carbon source, minimal $\mathrm{Fe}(\mathrm{II})$ was produced regardless of whether or not AQDS was present. Significantly lower Fe(II) production was observed in AQDS-free treatments. Interestingly, if AQDS was present, xylose-amended treatments showed the greatest $\mathrm{Fe}(\mathrm{II})$ production [2.9 $\mathrm{mM} \mathrm{Fe}(\mathrm{II})]$ but if AQDS was absent, molasses-amended treatments

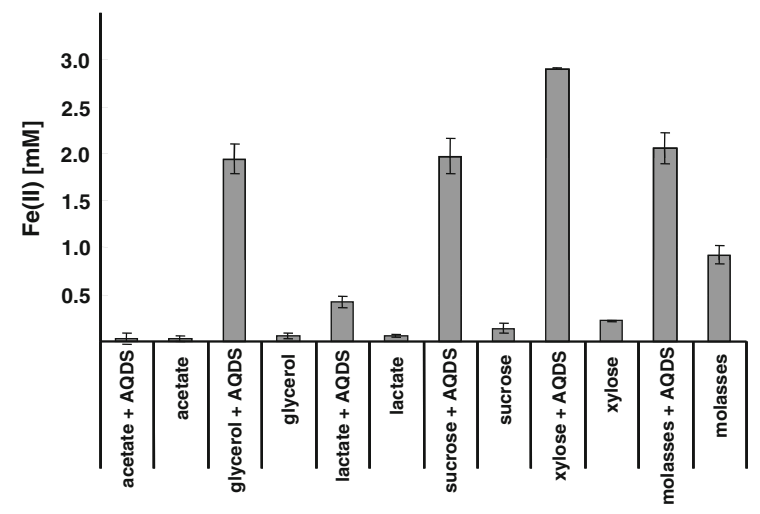

Fig. $3 \mathrm{Fe}$ (II) production from hydrous ferric oxide (HFO) by strain ES6 after 14 days of incubation in the presence and absence of different carbon sources $(10 \mathrm{mM}, 3.42 \mathrm{~g} / \mathrm{l}$ for molasses) and AQDS $(100 \mu \mathrm{M})$. Error bars represent \pm one standard deviation $(n=3)$ 
showed the greatest $\mathrm{Fe}(\mathrm{II})$ production $[0.92 \mathrm{mM}$ $\mathrm{Fe}(\mathrm{II})]$ compared to the other carbon sources. When AQDS was absent, no significant amounts of Fe(II) were produced except when molasses was the carbon source utilized.

Neither lactate, glycerol, nor acetate appeared to support bacterial growth (protein, CFU, and optical density, data for lactate in the presence of $3 \mathrm{mM}$ HFO can be seen in Fig. 1, other data not shown), but HFO reduction was observed in the presence of glycerol and lactate if $100 \mu \mathrm{M}$ of AQDS were present. Sterile controls with each carbon source \pm AQDS did not show significant $\mathrm{Fe}(\mathrm{III})$ reduction suggesting the reduction observed was not abiotic. Results suggest that bacterial growth was not necessary for Fe(III) reduction to occur. For each of the electron donors tested, $\mathrm{Fe}$ (II) production was lower in the absence of AQDS than in its presence. No statistically significant differences ( $t$-test, $P>0.05$ ) in biomass production were observed between AQDS amended and not AQDS amended treatments (data not shown). Hence, the increased production of Fe(II) in AQDS amended treatments was not the result of increased biomass production but was likely due to enhanced electron transfer from the bacterial cells to HFO.

These observations were reconfirmed in studies in which sucrose metabolism by strain ES6 was monitored in the presence and absence of HFO and AQDS. Substrate and metabolite measurements using ion chromatography indicated that lactate concentrations increased by approximately $25 \%$ in the presence of HFO and $40 \%$ in the presence of HFO with $100 \mu \mathrm{M}$ AQDS (data not shown). Formate concentrations also increased approximately $10 \%$ in these treatments indicating a more complete oxidation of sucrose in the presence of HFO and HFO plus AQDS. The presence of $100 \mu \mathrm{M}$ AQDS in the absence of HFO did not lead to any significant differences in metabolite patterns.

Electron shuttle influence on Fe(II) production

As AQDS was shown to increase HFO reduction rates, increasing AQDS concentrations were tested to determine if an increased concentration further increased HFO reduction rates. Results suggest increasing AQDS concentrations increased the rate of HFO reduction by strain ES6 in the presence of sucrose (Fig. 4). Initial Fe(III) reduction rates (inset to Fig. 4), normalized by the cell concentration (CFU), increased approximately tenfold from $2.27 \times$ $10^{-12} \pm 2.23 \times 10^{-13} \mu \mathrm{mol} \mathrm{Fe}(\mathrm{III}) / \mathrm{CFU} / \mathrm{h}$ in the absence of AQDS to $3.31 \times 10^{-11} \pm 3.34 \times 10^{-12} \mu \mathrm{mol}$ $\mathrm{Fe}(\mathrm{III}) / \mathrm{CFU} / \mathrm{h}$ in the presence of $500 \mu \mathrm{M}$ AQDS. Cell-free control treatments containing the highest AQDS concentration tested in this research $(500 \mu \mathrm{M})$ did not lead to significant HFO reduction again suggesting this was not an abiotic reaction.

$\mathrm{Fe}(\mathrm{III})$ reduction of different iron mineral phases

In the presence of $100 \mu \mathrm{M}$ AQDS and sucrose as the electron donor, HFO was the most readily reducible iron mineral among the ones tested as at least 10 times more $\mathrm{Fe}(\mathrm{II})$ was produced when HFO was the iron mineral present compared to any others (Fig. 5). No significant differences in $\mathrm{Fe}(\mathrm{II})$ produced were observed between the other iron minerals until day
Fig. 4 Influence of AQDS concentration on $\mathrm{Fe}(\mathrm{II})$ production from hydrous ferric oxide (HFO) by strain ES6 over time in the presence of sucrose. Inset Zero order Fe(II) production rates normalized to cell number. Error bars represent \pm one standard deviation $(n=3)$. Error bars are smaller than markers if not visible. Total amount of $\mathrm{Fe}$ (III) available in these experiments was $1.74 \mathrm{mmol} / \mathrm{l}$

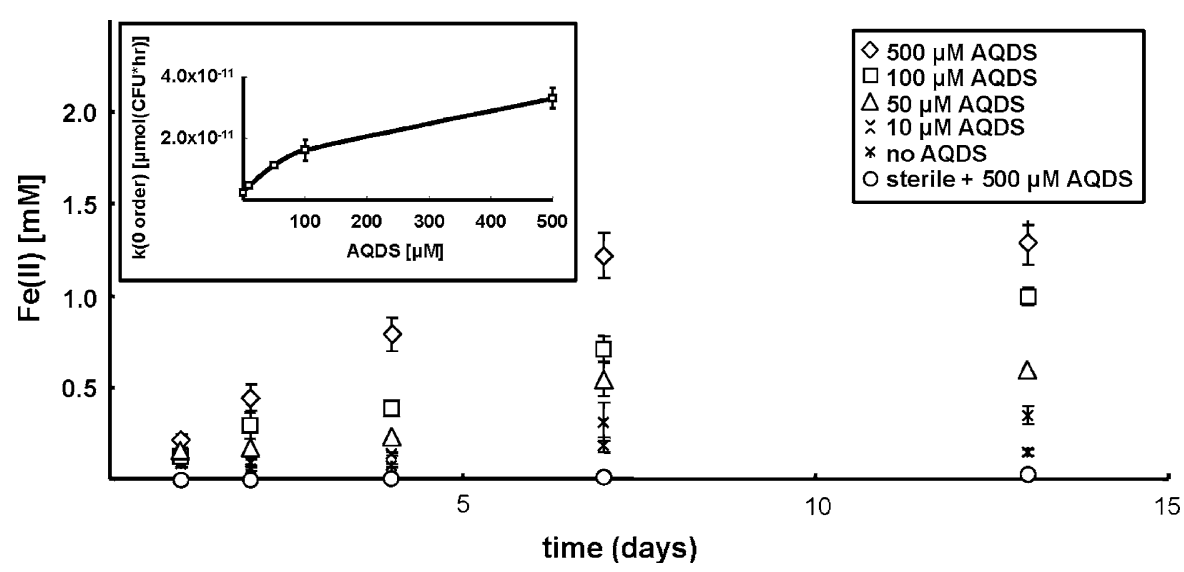


14. Results indicate $1.56 \mathrm{mM}$ Fe(II) was produced from HFO after 14 days while only 0.23 and $0.15 \mathrm{mM} \mathrm{Fe}$ (II) was produced by maghemite and magnetite, respectively. Goethite and hematite were not significantly reduced over the 14 days period although slight reduction of these minerals was observed in long term experiments ( $>50$ days) in the presence of AQDS (data not shown). It is possible that some of the $\mathrm{Fe}(\mathrm{II})$ produced in these experiments is originating from less crystalline $\mathrm{Fe}$ (III) phases present as impurities (up to $3 \%$ ) in the purchased iron mineral phases.

Since magnetite $\left(\mathrm{Fe}_{3} \mathrm{O}_{4}\right)$ already contains $\mathrm{Fe}(\mathrm{II})$ as part of its mineral structure, an increase in mild acidextractable $\mathrm{Fe}$ (II) could have been due to an increase in extractability over time. However, controls containing magnetite but lacking strain ES6 or AQDS did not show an increase in acid-extractable Fe(II) over the duration of the experiment. Thus, results indicate the increase in $0.5 \mathrm{~N} \mathrm{HCl}$-extractable Fe(II) observed for magnetite is due to microbial reduction of ferric iron.

Dissolved Fe(III) reduction in the presence of an electron shuttle

While the enhancement of $\mathrm{Fe}(\mathrm{III})$ mineral reduction in the presence of AQDS has been described and attributed to enhanced electron transport between the bacterial cell and solid phase Fe(III) (Lovley et al.

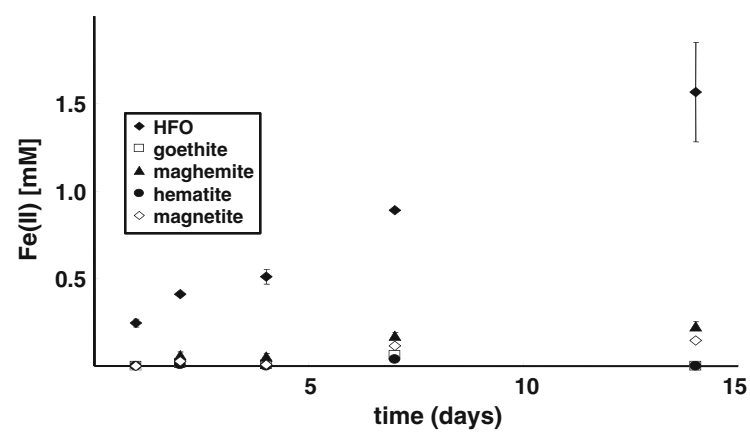

Fig. $5 \mathrm{Fe}(\mathrm{II})$ production over time from different Fe-minerals by strain ES6 in the presence of $100 \mu \mathrm{M}$ AQDS and sucrose. Error bars represent \pm one standard deviation $(n=3)$. Error bars are smaller than markers if not visible. Total amounts of $\mathrm{Fe}(\mathrm{III})$ available in these experiments were $3.58 \mathrm{mmol} / \mathrm{l}$ in the HFO containing treatments and $6 \mathrm{mmol} / \mathrm{l} \mathrm{Fe}(\mathrm{III})$ in the goethite, maghemite, hematite, and magnetite containing treatments
1998; Newman 2001; Royer et al. 2002b), reports of electron shuttling compound-enhanced dissolved phase $\mathrm{Fe}(\mathrm{III})$ reduction appear to be rare. The results of these studies indicate that the presence of the electron shuttle AQDS drastically enhanced the reduction of $\mathrm{Fe}(\mathrm{III})$-citrate by strain ES6 in the presence of sucrose as electron donor (Fig. 6). Reduction rates of $\mathrm{Fe}(\mathrm{III})$-citrate were generally higher than for HFO; ranging from $9.85 \times 10^{-12} \pm 3.10 \times 10^{-13} \mu \mathrm{mol}$ $\mathrm{Fe}(\mathrm{III}) / \mathrm{CFU} / \mathrm{h}$ without AQDS to $7.34 \times 10^{-11}$ $\pm 6.19 \times 10^{-12} \mu \mathrm{mol} \mathrm{Fe}(\mathrm{III}) / \mathrm{CFU} / \mathrm{h}$ for systems containing $500 \mu \mathrm{M}$ AQDS (inset to Fig. 6). These results indicate that soluble quinones, such as AQDS, can enhance the electron transport to solid phases and also to dissolved phase electron acceptors by strain ES6.

$\mathrm{Fe}(\mathrm{III})$ reduction in the presence of humic substances

While the addition of synthetic electron shuttling compounds such as AQDS to the environment might lack regulatory approval, the addition of natural organic matter such as humic and fulvic acids or humic substances should not encounter significant regulatory resistance. Hence, the influence of humic substances obtained from the International Humic Substance Society on the ability of strain ES6 to reduce HFO was also tested. Similar to the studies with AQDS, results demonstrate that the addition of the humic substances lead to an increase in $\mathrm{Fe}$ (II) production compared to controls lacking humic substances or lacking strain ES6 after 21 days (Fig. 7).

\section{Discussion}

Reductive transformation reactions for enhanced in situ bioremediation of oxidized environmental contaminants typically require an external electron donor. In most subsurface remediation scenarios, carbon sources such as those used in this study are considered the most convenient electron donor. The injection of readily available carbon can lead to biofouling of the injection wells or the surrounding formation (Roberts et al. 1991; Semprini et al. 1991; Shouche et al. 1993). Hence, it is important to be able to control the permeability of injection wells and the surrounding formation while maximizing microbial 
Fig. $6 \mathrm{Fe}(\mathrm{II})$ production from $\mathrm{Fe}(\mathrm{III})$-citrate by strain ES6 in the presence of sucrose and different AQDS concentrations over time. Inset Zero order reduction rates of $\mathrm{Fe}(\mathrm{II})$ production normalized to cell number. Error bars represent \pm one standard deviation $(n=3)$. Error bars are smaller than markers if not visible. Total amount of $\mathrm{Fe}$ (III) available: $4.26 \mathrm{mmol} / 1$

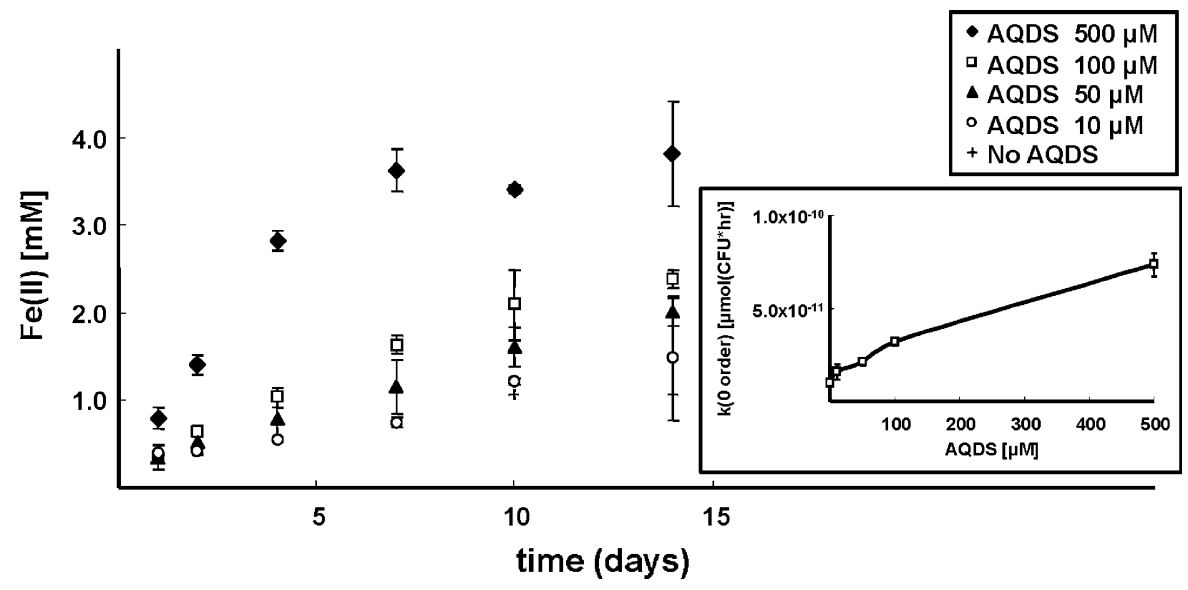

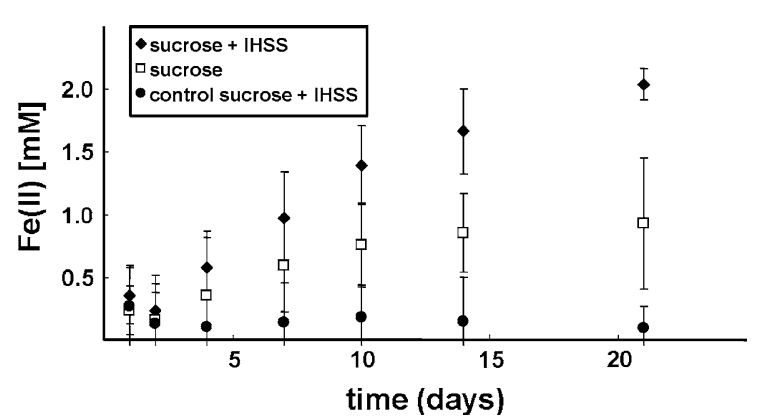

Fig. $7 \mathrm{Fe}(\mathrm{II})$ production over time from hydrous ferric oxide by ES6 in the presence and absence of humic substances with sucrose as electron donor. Error bars represent \pm one standard deviation $(n=3)$

activity. In this case, maximizing $\mathrm{Fe}(\mathrm{III})$ reduction while limiting microbial growth. The choice of electron donor will depend on which indigenous organisms are present and the type of electron acceptor(s) present. Facultative anaerobes, such as the strain ES6 investigated in this study, capable of respiration in the presence of oxygen and fermentation under anaerobic conditions can be selectively controlled by adding substrates that either do or do not support growth under the existing conditions.

Control of growth and $\mathrm{Fe}(\mathrm{III})$ reduction

Under anaerobic conditions, xylose appeared to support more growth than sucrose, while lactate and other short chain organic compounds supported little if any growth. Cellulomonas species are known to be capable of electron transport chain phosphorylation in the presence of oxygen (aerobic respiration) and substrate level phosphorylation (fermentation) in its absence (Stackebrandt et al. 2006). The energy yield is several times greater during aerobic respiration than during fermentation, thus explaining the lower amount of biomass produced in the absence of oxygen (Fig. 1). Lactate and other short chain organic compounds are not easily fermented explaining the lack of biomass production in their presence. In regards to lactate, these findings are consistent with Sani et al. (2002) who reported that lactate supported the reduction of NTA-chelated $\mathrm{Fe}$ (III) by Cellulomonas spp. under non-growth conditions, but anaerobic growth on $\mathrm{Fe}(\mathrm{III})$ as the terminal electron acceptor was not observed.

In the presence of oxygen, relatively inexpensive substrates such as lactate or glycerol as well as more complex substrates such as glucose, sucrose, or molasses can be used to build up biomass and consume oxygen. Once oxygen is consumed and no more biomass growth is desired, substrates can be added, which support reductive transformation reactions but no bacterial growth (e.g., lactate or glycerol). If additional growth of biomass is desired after oxygen has been consumed, sugars such as xylose or sucrose, or complex fermentable carbon sources such as molasses can be injected again.

Purified carbon sources, such as sucrose and xylose, are likely to be significantly more expensive than molasses, which often has sucrose as its main constituent (Prescott and Dunn 1983). Hence, molasses was tested in this study in order to include a fermentable carbon source with a high potential to be used in the field. In the absence of the electron shuttle 
AQDS, molasses supported the greatest amount of $\mathrm{Fe}$ (III) reduction from HFO after 14 days (Fig. 3), which is important as the addition of AQDS may not be approved for in situ applications or be far too expensive. Molasses also supported significantly more growth, based on viable cell counts, than any of the other carbon sources tested with no significant difference between AQDS and non-AQDS supplemented treatments (data not shown). The greater $\mathrm{Fe}(\mathrm{II})$ production in the molasses amended treatments could thus potentially be explained by the observed increased biomass production. Based on our research, it is however more likely that some of the molasses constituents other than sucrose either more readily provided electrons for HFO reduction or enhanced the electron transfer from strain ES6 to HFO, i.e., functioned as an electron shuttle. Separate experiments conducted in our laboratories investigated the reductive transformation of $\mathrm{Cr}(\mathrm{VI})$ (manuscript in preparation) by strain ES6. These experiments provided evidence that the increased reduction rates in the presence of molasses were due to molasses constituents that increase electron transfer rates from the bacterial cells and not due to increased biomass production since the addition of molasses in these treatments significantly increased reduction rates without increasing biomass production rates over the duration of these experiments.

\section{AQDS-enhanced Fe(III) reduction}

AQDS and other synthetic quinones are often used as model compounds for the quinone moieties of humic substances and have been shown to enhance the reduction of amorphous and crystalline solid phase $\mathrm{Fe}$ (III) by a wide range of bacteria (Benz et al. 1998; Lovley et al. 1998; Cervantes et al. 2002; Dong et al. 2003; Kappler et al. 2004; Luijten et al. 2004; Wolf et al. 2009). Our results demonstrate that the addition of AQDS and humic substances can significantly enhance the ability of strain ES6 to reduce solid phase Fe(III). The same is true for other Cellulomonas strains isolated from the Hanford site (data not shown).

The ability of strain ES6 to reduce HFO and $\mathrm{Fe}(\mathrm{III})$-citrate increased with increasing AQDS concentrations, which indicates that the addition of compounds rich in quinone moieties could be used to enhance electron transfer processes in subsurface environments containing microbial communities capable of fermentation. The influence of iron chelating or electron shuttling compounds on the reduction of solid phase $\mathrm{Fe}$ (III) has been investigated by other researchers (Zachara et al. 1998; Lovley and Blunt-Harris 1999; Royer et al. 2002a, b; Saffarini et al. 2002; Turick et al. 2002) and the results of this study are similar to their findings.

The results of this study suggest that strain ES6 was capable of reducing solid phase Fe(III) to some extent and the amount of $\mathrm{Fe}(\mathrm{II})$ produced increased with the addition of an electron shuttle. While overall these findings are similar to those studies performed with other microorganisms, the rate and extent of $\mathrm{Fe}$ (II) produced from these solid phase iron minerals is lower than some well-studied iron reducing microorganisms including Shewanella spp. (Kostka and Nealson 1995; Roden and Zachara 1996; Zachara et al. 1998; Dong et al. 2000; Royer et al. 2002b). However, it was observed that all of these solid phase iron minerals were reduced to some extent by strain ES6 even in the absence of an electron shuttle such as AQDS which was not observed in the case of the iron-reducing bacterium Deinococcus radiodurans (Fredrickson et al. 2000a). Additionally, Benz et al. (1998) demonstrated that Propionibacterium freudenreichii, a fermenting bacterium, was only capable of reducing HFO, maghemite and hematite in the presence of AQDS. Together, these results suggest that strain ES6 may not be able to reduce Fe(III) to the same extent or at the same rate as most iron respiring bacteria, but it may possess a greater ability to reduce iron than other fermenting bacteria. Therefore, Cellulomonas species may play a valuable role in $\mathrm{Fe}(\mathrm{III})$ reduction and subsequent contaminant transformations in subsurface environments.

The exact mechanism of how different compounds enhance solid phase $\mathrm{Fe}(\mathrm{III})$ reduction is not always obvious since some compounds are capable of both chelation of $\mathrm{Fe}(\mathrm{III})$ and electron shuttling. Humic substances for instance are commonly believed to both, chelate iron and shuttle electrons (Lovley et al. 1996; Lovley and Blunt-Harris 1999; Royer et al. 2002b). AQDS, a frequently used model compound in laboratory experiments, has been widely recognized as an electron shuttle only (Lovley et al. 1998; Newman 2001; Royer et al. 2002b). While Shyu et al. (2002) reported that AQDS can diffuse into the membrane of Shewanella oneidensis MR1 cells, the 
mechanism of electron transfer from bacterial cells to AQDS is not completely understood.

Several groups have reported that fermenting bacteria are able to shift their fermentation patterns to slightly more oxidized compounds in the presence of humic substances, electron shuttling compounds, or other potential electron acceptors (Emde and Schink 1990; Benz et al. 1998). With sucrose as the substrate, strain ES6 produced approximately $25 \%$ more lactate in the presence of HFO and approximately $40 \%$ more if $100 \mu \mathrm{M}$ AQDS were present in addition to HFO. The increased oxidation of sucrose in the presence of AQDS and HFO and the increased $\mathrm{Fe}(\mathrm{II})$ concentrations in these treatments indicate that more electrons can be transferred from sucrose to HFO in the presence of an electron shuttling compound. However, despite increased electron transfer to HFO and more oxidized fermentation products, no statistically significant difference in bacterial growth was observed. Assuming that the more extensive oxidation of sucrose in the presence of HFO or HFO and AQDS allowed strain ES6 to gain additional energy via substrate level phosphorylation, this additional energy was apparently not used to produce additional biomass. It is however possible that this additional energy was used to produce carbon storage compounds which would agree with observations made by Sani et al. (2002) and Viamajala et al. (2008).

The presence of quinone-like compounds capable of shuttling electrons, such as AQDS or humic substances, drastically increased the ability of strain ES6 to transfer electrons to solid phase Fe(III). While it has been shown that electron shuttling compounds such as AQDS can enhance the ability of several bacterial strains to reduce solid phase ferric iron, enhanced electron transfer from the bacterial cell to a dissolved electron acceptor has rarely been described. Figure 6 shows a significant increase in $\mathrm{Fe}(\mathrm{II})$ production rates from $\mathrm{Fe}(\mathrm{III})$-citrate in the presence of AQDS. Borch et al. (2005) showed that the addition of AQDS can considerably enhance the rate of TNT transformation by strain ES6 and we have shown in separate experiments that AQDS also drastically increases $\mathrm{Cr}(\mathrm{VI})$ reduction rates by strain ES6 (manuscript in preparation). The electron transfer from the reduced form of AQDS to dissolved $\mathrm{Fe}(\mathrm{III})$, TNT, or $\mathrm{Cr}(\mathrm{VI})$ is basically instantaneous. The rate of electron transfer to solid phase $\mathrm{Fe}(\mathrm{III})$ is likely limited by the number of available reducible surface sites.

The addition of synthetic compounds, such as AQDS, capable of increasing electron transfer from bacterial cells to oxidized contaminants or terminal electron acceptors, such as Fe(III)-minerals, could have economic potential. At this point in time however, the addition of synthetic electron shuttling compounds such as AQDS might lack regulatory approval because the effects of AQDS on the environment have not been studied extensively. AQDS has been shown to be toxic to a tolC mutant of S. oneidensis MR1 (Shyu et al. 2002) and methanogenic bacteria (Cervantes et al. 2000) in millimolar concentrations but no other toxicological data appear to be available. Concentrations used in this study were all below $500 \mu \mathrm{M}$, and other authors have reported that AQDS concentrations in the 50-100 $\mu \mathrm{M}$ range are sufficient for maximum Fe(III) reduction stimulation (Lovley et al. 1998; Royer et al. 2002b).

Humic substance-enhanced iron mineral reduction

The addition of natural organic matter such as humic and fulvic acids or humic substances should not encounter significant regulatory resistance. Thus, the addition of humic substances or fractions thereof have the potential to be successfully used in the field to enhance electron transfer from bacterial cells to oxidized contaminants or oxidized minerals. Humic substances obtained from the IHSS stimulated Fe(III) production from HFO although to a lesser extent than AQDS. A slight production of $\mathrm{Fe}(\mathrm{II})$ was observed in uninoculated controls containing these humic substances and is believed to be based on the abiotic reduction of $\mathrm{Fe}$ (III) by reduced humic substance moieties, such as reduced quinone structures (Kappler et al. 2004). The extent of stimulation by natural or synthetic organic matter is likely to depend on the number and reactivity of quinone-like structures, although compounds without quinone groups have also been reported to increase electron transfer from bacterial cells to $\mathrm{Fe}$ (III)-minerals (Hernandez et al. 2004). Additionally, the size and solubility of electron shuttling compounds are likely to play a role, such that insoluble fractions of natural organic matter for instance might not be as efficient in shuttling electrons as soluble fractions. 
Conversely, in a flowing environment, such as a contaminated aquifer, soluble fractions will likely be transported away from the treatment area with the flowing groundwater faster than fractions with low solubility and higher sorption tendency.

\section{Conclusions}

Important reactions involving dissolved and solid phase iron can be significantly influenced by fermenting, sulfate-reducing, halorespiring, and methanogenic bacteria (Benz et al. 1998; Cervantes et al. 2002; Kappler et al. 2004). This study demonstrates that the type of organic electron donor and other organic matter can significantly change the ability of Cellulomonas sp. strain ES6, a fermenting bacterium isolated from the Hanford site, to reduce dissolved and solid phase $\mathrm{Fe}(\mathrm{III})$.

It appears from our results that, while strain ES6 possesses a limited ability for $\mathrm{Fe}(\mathrm{III})$ reduction compared to iron respiring bacteria, it might possess a greater ability to reduce iron than other fermenting bacteria. This makes strain ES6 a potentially important organism for in situ contaminant remediation. Results demonstrate that carbon sources can be selected to control growth at least partly independently from $\mathrm{Fe}$ (III) reduction. In the potential application of in situ biobarriers in the field, this could be an important method for controlling the bacterial density and activity in subsurface environments and hence provide a mechanism to avoid the plugging of injection wells by gaining some control over subsurface bacterial growth.

While the reduction of $\mathrm{Fe}$ (III) minerals by respiratory metal-reducing bacteria such as Shewanella and Geobacter has been described intensively over the past decade, the importance of other genera on the iron cycle and contaminant transformations have received much less attention. Although Lovley (1987) reported that a large number of bacteria can reduce, but not grow on $\mathrm{Fe}(\mathrm{III})$ as their sole terminal electron acceptor, it was only recently accepted that these bacteria can have a significant influence on oxidation-reduction reactions in the environment. Based on the results presented here and recent results by Benz et al. (1998), Cervantes et al. (2002), Kappler et al. (2004), and Luijten et al. (2004) we suggest that the presence of bacteria other than respiratory iron reducers, can be sufficient to achieve significant reduction of subsurface iron minerals especially in the presence of even very low concentrations of natural or synthetic organic matter. Reduced iron minerals could then serve to reductively transform oxidized contaminants such as $\mathrm{Cr}(\mathrm{VI})$, U(VI), trinitrotoluene, or chlorinated aliphatic compounds.

Acknowledgments The authors thank Kristy Weaver and Laura Jennings for their assistance in the laboratory. This research was supported by the U.S. Department of Energy, Office of Science, Environmental Management Science Program, under Grant No. DE-FG02-03ER63582 and DOENE Idaho Operations Office Contract DE-AC07-05ID14517. Partial financial support was provided by a grant from the Inland Northwest Research Alliance (INRA) under contract MSU 002.

\section{References}

Amonette J, Workman D, Kennedy D, Fruchter J, Gorby Y (2000) Dechlorination of carbon tetrachloride by Fe(II) associated with goethite. Environ Sci Technol 34:46064613

Bauer I, Kappler A (2009) Rates and extent of reduction of $\mathrm{Fe}(\mathrm{III})$ and $\mathrm{O}_{2}$ by humic substances. Environ Sci Technol 43:4902-4908

Benz M, Schink B, Brune A (1998) Humic acid reduction by Propionibacterium freudenreichii and other fermenting bacteria. Appl Environ Microbiol 64:4507-4512

Borch T, Inskeep W, Harwood J, Gerlach R (2005) Impact of ferrihydrite and anthraquinone-2,6-disulfonate on the reductive transformation of 2,4,6-trinitrotoluene by a gram-positive fermenting bacterium. Environ Sci Technol 39:7126-7133

Bradford M (1976) A rapid and sensitive method for the quantification of microgram quantities of protein using the principle of protein-dye release. Anal Biochem 72: 248-254

Cervantes F, Velde S, Lettinga G, Field J (2000) Competition between methanogenesis and quinone respiration for ecologically important substrates in anaerobic consortia. FEMS Microbiol Ecol 34:161-171

Cervantes F, de Bok F, Duong-Dac T, Stams A, Lettinga G, Field J (2002) Reduction of humic substances by halorespiring, sulphate-reducing and methanogenic microorganisms. Environ Microbiol 4:51-57

Chilakapati A, Williams M, Yabusaki S, Cole C, Szecsody J (2000) Optimal design of an in situ Fe(II) barrier: transport limited reoxidation. Environ Sci Technol 34:52155221

Cooper D, Picardal F, Rivera J, Talbot C (2000) Zinc immobilization and magnetite formation via ferric oxide reduction by Shewanella putrefaciens 200. Environ Sci Technol 34:100-106 
Dong H, Fredrickson J, Kennedy D, Zachara J, Kukkadapu R, Onstott T (2000) Mineral transformations associated with the microbial reduction of magnetite. Chem Geol 169:299-318

Dong H, Kukkadapu RK, Fredrickson JK, Zachara JM, Kennedy DW, Kostandarithes HM (2003) Microbial Reduction of Structural Fe(III) in Illite and Goethite. Environ Sci Technol 37:1268-1276

Eary L, Rai D (1988) Chromate removal from aqueous wastes by reduction with ferrous ion. Environ Sci Technol 22: 972-977

Emde R, Schink B (1990) Oxidation of glycerol, lactate, and propionate by Propionibacterium freudenreichii in a poised-potential amperometric culture system. Arch Microbiol 153:506-512

Erbs M, Hansen H, Olsen C (1999) Reductive dechlorination of carbon tetrachloride using iron (II) iron (III) hydroxide sulfate (green rust). Environ Sci Technol 33:307-311

Fredrickson J, Zachara J, Kennedy D, Dong H, Onstott T, Hinman N, Li S (1998) Biogenic iron mineralization accompanying the dissimilatory reduction of hydrous ferric oxide by a groundwater bacterium. Geochim Cosmochim Acta 62:3239-3257

Fredrickson J, Kostandarithes H, Li S, Plymale A, Daly M (2000a) Reduction of Fe(III), Cr(VI), U(VI), and Tc(VII) by Deinococcus radiodurans R1. Appl Environ Microbiol 66:2006-2011

Fredrickson J, Zachara J, Kennedy D, Duff M, Gorby Y, Li S, Krupka K (2000b) Reduction of U(VI) in goethite (a-FeOOH) suspensions by a dissimilatory metal-reducing bacterium. Geochim Cosmochim Acta 64:3085-3098

Heijman C, Grieder E, Holliger C, Schwarzenbach R (1995) Reduction of nitroaromatic compounds coupled to microbial iron reduction in laboratory aquifer columns. Environ Sci Technol 29:775-783

Hernandez M, Kappler A, Newman D (2004) Phenazines and other redox-active antibiotics promote microbial mineral reduction. Appl Environ Microbiol 70:921-928

Hofstetter T, Schwarzenbach R, Haderlein S (2003) Reactivity of $\mathrm{Fe}(\mathrm{II})$ species associated with clay minerals. Environ Sci Technol 37:519-528

Istok J, Amonette J, Cole C, Fruchter J, Humphrey M, Szecsody J, Teel S, Vermeul V, Williams M, Yabusaki S (1999) In situ redox manipulation by dithionite injection: intermediate-scale laboratory experiments. Ground Water 37:884-889

Jiang J, Kappler A (2008) Kinetics of microbial and chemical reduction of humic substances: implications for electron shuttling. Environ Sci Technol 42:3563-3569

Kappler A, Benz M, Schink B, Brune A (2004) Electron shuttling via humic acids in microbial iron(III) reduction in a freshwater sediment. FEMS Microbiol Ecol 47:85-92

Kostka J, Nealson K (1995) Dissolution and reduction of magnetite by bacteria. Environ Sci Technol 29:25352540

Lee W, Batchelor B (2002a) Abiotic reductive dechlorination of chlorinated ethylenes by iron-bearing soil minerals. 1 . Pyrite and magnetite. Environ Sci Technol 36:5147-5154

Lee W, Batchelor B (2002b) Abiotic reductive dechlorination of chlorinated ethylenes by iron-bearing soil minerals. 2 . Green rust. Environ Sci Technol 36:5348-5354
Liu C, Gorby Y, Zachara J, Fredrickson J, Brown C (2002) Reduction kinetics of $\mathrm{Fe}(\mathrm{III}), \mathrm{Co}(\mathrm{III}), \mathrm{U}(\mathrm{VI}), \mathrm{Cr}(\mathrm{VI})$, and $\mathrm{Tc}(\mathrm{VII})$ in cultures of dissimilatory metal-reducing bacteria. Biotechnol Bioeng 80:637-649

Lovley D (1987) Organic matter mineralization with the reduction of ferric iron: a review. Geomicrobiol $\mathrm{J}$ 5: 375-399

Lovley D (1997) Microbial Fe(III) reduction in subsurface environments. FEMS Microbiol Rev 20:305-313

Lovley D, Blunt-Harris E (1999) Role of humic-bound iron as an electron transfer agent in dissimilatory $\mathrm{Fe}(\mathrm{III})$ reduction. Appl Environ Microbiol 65:4252-4254

Lovley D, Phillips E (1986a) Availability of ferric iron for microbial reduction in bottom sediments of the freshwater tidal Potomac River. Appl Environ Microbiol 52:751-757

Lovley D, Phillips E (1986b) Organic matter mineralization with reduction of ferric iron in anaerobic sediments. Appl Environ Microbiol 51:683-689

Lovley D, Phillips E, Lonergan D (1991) Enzymatic versus nonenzymatic mechanisms for Fe(III) reduction in aquatic sediments. Environ Sci Technol 25:1062-1067

Lovley D, Coates J, Blunt-Harris E, Phillips E, Woodward J (1996) Humic substances as electron acceptors for microbial respiration. Nature 382:445-448

Lovley D, Fraga J, Blunt-Harris E, Hayes L, Phillips E, Coates J (1998) Humic substances as a mediator for microbially catalyzed metal reduction. Acta Hydrochim Hydrobiol 26:152-157

Luijten M, Weelink S, Godschalk B, Langenhoff A, Eekert M, Schraa G, Stams A (2004) Anaerobic reduction and oxidation of quinone moieties and the reduction of oxidized metals by halorespiring and related organisms. FEMS Microbiol Ecol 49:145-150

Nealson K, Saffarini D (1994) Iron and manganese in anaerobic respiration: environmental significance, physiology, and regulation. Ann Rev Microbiol 48:311-343

Nevin K, Lovley D (2000) Potential for nonenzymatic reduction of $\mathrm{Fe}(\mathrm{III})$ via electron shuttling in subsurface sediments. Environ Sci Technol 34:2472-2478

Newman D (2001) How bacteria respire minerals. Science 292:1312-1313

Petersen J, Skeen R, Amos K, Hooker B (1994) Biological destruction of $\mathrm{CCl}_{4}$ : I. Experimental design and data. Biotechnol Bioeng 43:521-528

Prescott S, Dunn C (1983) Prescott and Dunn's industrial microbiology. AVI Publishing Company, Inc, Westport

Roberts P, Hopkins G, Semprini L, McCarty P, MacKay D (1991) Pulsing of electron donor and electron acceptor for enhanced biotransformation of chemicals. U.S. Patent $5,006,250$

Roden E, Zachara J (1996) Microbial reduction of crystalline iron (III) oxides: influence of oxide surface area and potential for cell growth. Environ Sci Technol 30: $1618-1628$

Royer R, Burgos W, Fisher A, Jeon B, Unz R, Dempsey B (2002a) Enhancement of hematite bioreduction by natural organic matter. Environ Sci Technol 36:2897-2904

Royer R, Burgos W, Fisher A, Unz R, Dempsey B (2002b) Enhancement of biological reduction of hematite by electron shuttling and Fe(II) complexation. Environ Sci Technol 36:1939-1946 
Saffarini D, Blumerman S, Mansoorabadi K (2002) Role of menaquinones in $\mathrm{Fe}(\mathrm{III})$ reduction by membrane fractions of Shewanella putrefaciens. J Bacteriol 184:846-848

Sani R, Peyton B, Smith W, Apel W, Petersen J (2002) Dissimilatory reduction of $\mathrm{Cr}(\mathrm{VI}), \mathrm{Fe}(\mathrm{III})$, and $\mathrm{U}(\mathrm{VI})$ by Cellulomonas isolates. Appl Microbiol Biotechnol 60:192-199

Semprini L, Hopkins G, Janssen D, Lang M, Roberts P, McCarty P (1991) In situ biotransformation of carbon tetrachloride under anoxic conditions. EPA Report No. EPA 2-90/060. US EPA, Ada

Shouche M, Petersen J, Skeen R (1993) Use of a mathematical model for prediction of optimum feeding strategies for in situ bioremediation. Appl Biochem Biotechnol 39: 763-779

Shyu J, Lies D, Newman D (2002) Protective role of tolC in efflux of the electron shuttle anthraquinone-2,6-disulfonate. J Bacteriol 184:1806-1810

Smith W, Apel W, Petersen J, Peyton B (2002) Effect of carbon and energy source on bacterial chromate reduction. Biorem J 6:205-215

Stackebrandt E, Schumann P, Prauser H (2006) The family Cellulomonadaceae. In: Dworkin M, Falkow S, Rosenberg E, Schleifer K, Stackebrandt E (eds) The prokaryotes, vol 3, 3rd edn. Springer Science \& Business Media, LLC, New York, pp 983-1001
Turick C, Tisa L, Caccavo F Jr (2002) Melanin production and use as a soluble electron shuttle for Fe(III) oxide reduction and as a terminal electron acceptor by Shewanella algae BrY. Appl Environ Microbiol 68:2436-2444

Viamajala S, Smith W, Sani R, Apel W, Petersen J, Neal A, Roberto F, Newby D, Peyton B (2007) Isolation and characterization of $\mathrm{Cr}(\mathrm{VI})$ reducing Cellulomonas spp. from subsurface soils: implications for long-term chromate reduction. Bioresour Technol 98:612-622

Viamajala S, Gerlach R, Sivaswamy V, Peyton BM, Apel WA, Cunningham AB, Petersen JN (2008) Permeable reactive biobarriers for in situ $\mathrm{Cr}(\mathrm{VI})$ reduction: bench scale tests using Cellulomonas sp. strain ES6. Biotechnol Bioeng 101(6):1150-1162

Wolf M, Kappler A, Jiang J, Meckenstock RU (2009) Effects of humic substances and quinones at low concentrations on ferrihydrite reduction by Geobacter metallireducens. Environ Sci Technol 43:5679-5685

Yin Y, Allen H (1999) Technology evaluation report: in situ chemical treatment. Ground Water Remediation Technologies Analysis Center TE-99-01 1, pp 1-74

Zachara J, Fredrickson J, Li S, Kennedy D, Smith S, Gassman $\mathrm{P}$ (1998) Bacterial reduction of crystalline $\mathrm{Fe}^{3+}$ oxides in single phase suspensions and subsurface materials. Am Miner 83:1426-1443 